\title{
FACTORS AFFECTING THE INITIAL LITERACY DEVELOPMENT OF URBAN AND RURAL LEARNERS IN THE IGANGA DISTRICT, UGANDA
}

Felix Banda \& Rebecca Kirunda

University of the Western Cape

The initial motivation for the study was data from the Ministry of Education in Uganda that suggests that in terms of academic performance, urban learners continually outperform rural schools at primary and secondary school levels (Ministry of Education 2002). At present all government examinations are written in English. However, the language in education policy in Uganda differentially stipulates the use English as medium of instruction in urban schools and the use of the mother tongue in rural schools (cf. Kyeyune 2004). Other factors which mitigate against rural learners' successful academic performance are untrained educators, poor infrastructure and school management practices in rural schools, poverty, lack of supportive academic discourse practices, and a general lack of enthusiasm among rural parents (most of whom have very little formal education) for their children's education.

Using data from observations of selected urban and rural homes and schools in The Iganga district and field notes in the form of diary entries, the study draws on New Literacy Studies (NLS) particularly the notion of literacy as social practice (Street 2001; Gee 2000; Baynham 2000, 2001), to explore the differential effect of urban and rural-based acculturation processes on the initial literacy development of learners. Finally, since $88 \%$ of Ugandans live in rural areas (Uganda Bureau of Statistics 2002), the pedagogical implications for primary schools are discussed and suggestions are made on how to establish an inclusive education system.

\section{INTRODUCTION}

The initial motivation for this study was data from the Ugandan government and Ministry of Education on academic performance at primary and secondary levels that suggest that urban schools outperform rural schools. Year after year the reports given indicate excellent performance for the urban schools and poor performance for the rural schools (see Ministry of Education, 2002). The magnitude of the problem should be measured against the fact that the 2002 census report indicates that $88 \%$ of the Ugandan population live in rural areas. According to this census, the Iganga district - the site for this study - had a population of 714 635, ninth out of the 56 districts (Uganda Bureau of Statistics, 2002). Socio-economic development in Uganda will require making provision for this rural population. At present, however, because of language in education policy (such as the use of English in all government school examinations) and socio-cultural barriers, rural people find it difficult to break out of the cycle of poverty and academic literacy deprivation for their children. This 
brings us to the second argument, that is, the role of parents in the education, socialisation and acculturation of learners. The central argument of the New Literacy Studies (NLS) is that literacy is a social practice embedded in people's lives (Barton, 1999; Machet 2001; Street, 2001) so the importance of family participation in the children's literacy development cannot be overemphasised.

This article draws on NLS, particularly, on the notion that literacy is a social practice (Barton, 1999; Baynham, 2000, 2001; Gee, 2000; Street, 2001; Prinsloo \& Breier, 1996) in attempting to explore the following research question: Do acculturation processes embedded in urban and rural areas and homes have a differential effect on literacy practices, and concomitantly on the differential academic competences of rural and urban primary school learners?

In addressing this question, the article tries to demonstrate how socio-acculturation processes initiated and scaffolded in a child's 'way of life' at his/her home promote academic success or failure. As Barton (1999: 69) points out, anything said about literacy presupposes a perspective on language in general, as being 'literate' is always related to a particular language. In addition, the role of language in education policy in promoting or hindering academic performance will also be explored. Using illustrations from the Iganga district, we shall suggest why urban learners generally do better than rural learners at school, and suggest ways in which the increasing gap in academic performance between urban learners and rural learners could be reduced.

\section{THEORETICAL AND CONCEPTUAL FRAMEWORK}

In this study, the terms culture, process, acculturation, literacy, literacy events and literacy practices are seminal to the discussion, and so need to be defined. Brian Street argues that 'culture is a verb' (Street, 1993; 2000: 19). The use of the word 'culture', therefore, implies that culture is a process which is negotiated and contested rather than fixed and unchanging. Concomitantly, culture is not construed as a given inventory of characteristics (Street, 1993; 2000:19; Martin-Jones \& Jones, 2000: 14-15). The term 'process' in relation to culture, implies an on-going or continuous action, happening or event. This assertion has its roots in the New Literacy Studies (NLS) in which the word culture refers to a process. In this study, the term acculturation is used to describe the cultural process of instilling useful practices in children. Hence we use the term 'acculturation' to describe the process in which children acquire literacy practices.

The meaning accorded to the word literacy varies greatly. For example, in modern education systems and many Literacy Agencies literacy is represented as a set of functional skills (Street, 2000: 23). Once acquired they automatically improve people's cognitive functioning and equip them with greater facility of abstraction, logical thought and metalinguistic awareness, thus making them eligible for jobs and economic success (Street, 1995: 2). However, as we have already argued, NLS contests this view. NLS takes the view that in this kind of perception literacy turns out to be a means of strengthening processes of discriminatory power relations, practices, competing discourses and hegemony rather than of exploring the great divide and the rationality of 'modern' and 'traditional' societies (Street, 2000: 25). Therefore the autonomous model increases the divide between those acknowledged as literate and the 'illiterate'. 
Literacy is a social practice (cf. Barton, 1999; Baynham, 2000; Gee, 2000; Prinsloo \& Breier, 1996; Street, 2001; 2001).This premise is based on the fact that literacy permeates people's political, social, cultural, and, in fact, almost all aspects of life: Literacy is embedded in the activities of people's ordinary lives whether or not they regularly read books or do much writing (Barton, 1999: 4). These are termed literacy events. This phrase derives its meaning from the sociolinguistic idea of a 'speech event' (Hymes, 1972), which according to Anderson, Teale and Estrada (1980) is a social occasion during which a person attempts to comprehend graphic signs. Similarly Heath (1982: 93) sees a literacy event as 'any social occasion in which a piece of writing is integral to the nature of the participants' interactions and their interpretive process'.

Street (2000: 21) argues that the concept, 'literacy event', is helpful in that it helps us to focus on a particular situation where things are happening and you can see them happening. He calls this the classic literacy event in which we are able to observe an event which involves reading and/or writing and begin to draw out its characteristics. Examples of such events in our lives include reading a newspaper, making a shopping list or writing a letter. Reading here includes print literacy (Prinsloo \& Breier, 1996: 24; Barton, 1999: 23) as well as events related to reading and writing images (Kress \& Leeuwen, 1996). The notion of literacy events, then, takes us to that of 'literacy practices' which Street (1984: 1; 2000: 20) employs to focus on the 'social practices and conceptions of reading and writing'. The concept of literacy practices attempts to handle the events and the patterns of activity around literacy, linking them to broader socio-cultural aspects (cf. Street, 2000; Gee, 2000). This enables us to link a literacy event to literacy practices specific to socio-cultural contexts. In turn, this allows us to incorporate concepts and social models of the nature of the practices in the study of literacy practices as well as what makes particular practices work, giving them meaning. Hence literacy practices refer to the broader cultural conception of particular ways of thinking about and doing reading and writing in cultural contexts. In Street's fieldwork in Iran, for example, the literacy practices that emerged were uses and meanings of literacy that were identifiable around three domains of social activity: Maktub literacy practices, schooled literacy practices, and commercial literacy practices (Street, 2000: 22). That is why many researchers prefer to adopt the phrase 'multiple literacies' to acknowledge the multiplicity nature of literacy in any given cultural context.

This underpins the view of literacy as related to situations in which people are able to participate in both literacy events and literacy practices to which they attach both meaning and value. In this paper we take literacy practices to encompass literacy events in particular situations where activities involving reading and/or writing take place, and in which the patterns of activity around literacy are linked to the broader cultural and social context (cf. Street, 2000).

NLS theorists contend that literacy practices vary within cultural contexts. They argue that there is not a single, monolithic, autonomous literacy whose consequences for individuals and societies can be read off as a results of its intrinsic characteristics: rather there are literacies or literacy practices whose character and consequences have to be specified in each context (Barton, 1999; Barton \& Ivanic, 1991; Collins, 1995; Finnegan, 1973, 1988; Gee, 1990, 2000; Street, 1984, 1995, 2000: 25). The implication for this study was that literacy practices, especially those involving childen had to be observed. Examples of such practices are learning the alphabet from the age of two years and doing homework with the parents' help. It also involved identifying the kinds of literacy practices in rural homes such as children 
reading and interpreting their school reports for their parents. The examples of activities/literacy practices given here are different in character; all have different consequences for the participants and they take place in specified contexts. It is important to note that what is happening in each context is of great value to the participants.

Proponents of NLS contend that in such cases those in power retain their power while pretending to provide access to facilities for the disempowered. However, the status quo could change if people challenged it. This paper takes that proposition seriously especially in the view of Uganda's language in education policy, which advantages urban learners, particularly those who are proficient in English. In this paper, we will attempt to show how the current language in education policy empowers urban learners rather than rural learners. In South Africa, the situation is not very different, as can be seen from the recent debates on the (de)merits of the use of English as medium of instruction for mother tongue speakers of African languages in primary schools. It can thus be argued that even in South Africa, it is the rural African language learner, who, unlike his/her urban counterpart, had never heard English outside the school environment, suffers more from current policies on assessment.

In opposing the autonomous model NLS advocates for 'real literacies', participatory literacy and empowerment that takes a more socially-oriented perspective and focuses more precisely on local conditions (Street, 2000: 26). Studies in this field have focused on making the existing literacies that people have useful. This is of great value to educators in particular. It implies that teachers should endeavour to find out the supportive literacy practices children bring with them when they come to school and use them to develop the schooled literacies that will lead to high academic achievement (Gee, 1990, 2000; Street, 2001).

\section{THE STUDY}

\section{The site}

The site for the study was the Iganga district. The Iganga district is one of the 56 districts in Uganda. It is 150 kilometres east of Kampala, the country's capital city. Like all the other districts, the Iganga district has both the rural and the urban settings. The rural-urban divide is determined by a particular place's proximity from Iganga town which is the main urban area. Uganda's urban areas have, for a long time, been centres of attraction to the Ugandan population in general and the elite in particular because they offer more employment opportunities. In addition these areas have better social amenities and infrastructure. Hence, Uganda, like most developing countries, has had her share of the rural-urban drift as people move to look for employment. Families move from all over the country and go to settle in the urban areas.

\section{Data collection}

The data was collected during observations in the homes of the children, pen and paper and audio recording of interviews and focus group discussions with parents in urban and rural Iganga. The home visits lasted for 4 months.

A total of six (6) homes were visited. Three of these were in the rural area while the other three were in the urban setting. The researchers spent at least eight hours in each home. The 
objective of the visits was to observe and record the literacy practices and artefacts in place, what went on in the homes, and to talk to the children, the parents and the other people who were in the homes about their literacy experiences.

We should point out from the outset that we do not have enough evidence to argue that the homes visited in urban or rural areas are representative of all homes in the Iganga district. The urban homes can, however, be described as representing the African middleclass in Uganda. In terms of social stratification and socioeconomic status, this is the group from which policy makers are drawn, which also represents the ideals, values, and ideology contained in the language policy in which urban schools have been promulgated to use English as medium of instruction. In addition, this is the group people in society aspire to emulate - that is, to be (well) educated and successful socio-economically. What we offer is what we observed in these particular homes, that is what is available in terms literacy practices and artefacts, and what they suggest about the differential impact of acculturation in urban and rural areas, and how this in turn leads to differential literacy practices in the two domains, which in turn still, could be said to lead to markedly different academic performance between urban and rural learners.

\section{FINDINGS}

Table 1 compares the literacy activities and artefacts observed in the urban and the rural homes visited. As can be seen, there is some overlap. What the chart highlights is how little print there is in the rural environment, unlike the urban homes where children are exposed to a variety of print such as charts on the walls, newspapers and other media, books and labels. There are also few opportunities for discussion. Because their parents have had very little formal education, they do not engage in reading and writing activities, which means that children do not have the rich multimodal experience urban children enjoy.

These observations are congruent with information obtained during the focus group discussions with parents.

\section{Focus group discussions with urban parents}

Focus group discussions were held with urban parents. The group included the parents from the homes where literacy practices were observed. It was evident from follow up discussions with urban parents that they do their best to organise reading and writing activities for their children. They said they start doing this very early, when children are around two years of age. They buy charts and books starting with picture books. They continue buying the books even when the children start school. They often set aside some time to 'read with their children'. As one parent explained:

...this starts with just seeing and talking about the pictures with the children, any pictures, be they in the newspapers or in those little books we buy for them. Gradually you move from one level to another.

They said they teach them songs such as counting rhymes and give them pencils and paper so that they can doodle. They said that they do that often especially when they are busy with their own paper work and they want to avoid disturbance from the children. When the 
children start school the parents always make sure that the homework is done and done correctly.

In addition the urban parents said that their children watch $\mathrm{TV}$ and listen to radio programmes. This is what one parent had to say:

When they are young they like cartoons but expand the watching scope as they grow, eventually you start suggesting some good programmes for them some of which you make an effort to watch and discuss with them.

\section{\begin{tabular}{l}
\hline Urban homes \\
\hline \hline - Read newspapers, magazines and brochures. \\
- Charts for nursery school on walls. Alphabet \\
with sets of words and pictures.
\end{tabular}}

- Read labels on food and medicine packs.

- Visit public libraries, borrow and read the books; also read books from home libraries as well as textbooks and supplementary readers.

- Are read to and they read with their parents and siblings from a tender age; read and write messages (parents, phone, callers).

- Revise their notes or do other homework

- Do homework given by the teachers and more is organised by the parents.

- Make, cost and use shopping lists.

- Some write letters to friends and colleagues.

- Children go to theatre and watch plays acted in English and/or Luganda.

- Watch TV and films and listen to the radio; discussion of programmes with the people around them e.g. parents and siblings

- The urban children engage in 'debate' with the parents, teachers and/or with other older and more experienced people over various issues.

- Discuss their academic work with peers and parents.

- Play 'mind' games like scrabble and work with word puzzles

\section{Rural homes}

- No evidence of newspapers, magazines and brochures.

- No charts or pictures on the wall.

- No food or medicine labels to read as parents do not usually buy food. They get it from their garden. Medicine from the shops is too expensive.

- There are no libraries (public or home); sometimes borrow and read some of the school textbooks from teachers.

- There are hardly any written materials and they don't watch their parents read and write anything.

- Only in a few homes is homework done.

- Sometimes children only have to read and interpret their reports for their parents, but this happens only three times a year.

- Children have to help with chores when they come home from school so there is not much time to listen to folk stories.

- Rarely listen to radio.

- For cultural reasons, cannot discuss much with their parents.

- Occasionally discuss their academic work with peers, but rarely with parents.

Table 1 Summary of literacy activities and artefacts in the rural and urban homes that formed part of the study 
They also said that their children listen to radio and together they discuss the programmes. Another important factor they mentioned was that they endeavour as much as they can to answer any questions the children ask.

\section{Focus group discussions with rural parents}

The rural parents conceded that the rural learners lack access to many literacy artefacts which could have exposed them to information, those which give them pleasure specifically the TV and, those which can help develop self expression. They admitted that they rarely create opportunities for their children to read or write at home. One rural parent conceded that:

...except maybe to ask them to read or write a letter for you but this is just once in a while. Some times we ask them to read and translate their reports for us but it is better to ask another adult to do that for you.

They intimated that it is rare to find children in rural areas reading on their own. They observed that the common literacy practice their children engage in is revising their notes but this is usually done by a few and only during the examination period. They said that in a few homes, sometimes the children do some homework and discuss their schoolwork with their peers, some of the visitors or their siblings. According to what they said, however, this is also rare because the children rarely bring any homework to be done at home. But they said that when the children take home their homework they (the parents) tell them to do it mainly after supper, as they have to help with house chores, such as fetching firewood from the forest or drawing water from the stream. But after attending to the chores 'most of the times the children just doze off because they are already tired'. Three of the parents said that they try to help when the children are in lower classes '...but when things get tough we ask the older siblings to help, or we just leave it to the teachers...'.

As already noted elsewhere in this study there are no TVs in rural areas. But the parents said that sometimes the children listen to the radio but mainly to programmes in their mother tongue or football matches or music programmes.

\section{Pedagogical Implications}

It is evident that the urban children in the study live in an environment that is rich in literacy practices in which they are fully involved. In the rural areas, the environment is impoverished in terms of opportunities to engage in literacy practices that are school-related. The urban children in the study not only have access to high quality community literacies but also have many opportunities to enhance the development of their supportive listening, speaking, reading and writing skills, which are so vital in the learning process.

It is also apparent in the study that the children in urban homes have a lot of access to information from supportive literacy artefacts. The implication is that the urban children gain a lot of information and knowledge from all these activities and artefacts that turn out to be very helpful in their academic tasks. In addition, we observed that all the artefacts, books and newspapers were written in English, the language of the academic discourse.

It is noteworthy that exposure to the language of study/examinations and discourse practices closely related to academic discourse give learners opportunities to develop their language 
proficiency in that regard, which tends to have a positive effect on their academic success. (NCCRD, 2000; Machet, 2001: 4; Barton, 1999; Saxena, 1994; McGroarty 1996:19).

In line with what Hall (1994) found, the urban learners are also exposed to print as well as the audio-visual, right from their childhood. They grow up reading words and images, in addition to watching their parents work with books. As one of the parents put it:

To avoid a lot of disturbance you give the child a book or paper and a pen to keep them busy doodling as you work. As they grow you introduce some meaningful work. You write for them numbers and letters and tell them to write as they copy what you have written for them.

After using the displayed charts and watching the parents and siblings working with books in the urban homes, by the time these children go to school, they are conversant with books. They know how to handle them the right side up and thus, they are many steps ahead of the rural children who are just coming in contact with the books for the first time. The urban children already know how to handle pencils as they have watched and have been guided by their parents.

Similar situations attend in South Africa as can be deduced from Machet's study on addressing literacy problems in disadvantaged communities in South Africa:

Family practices actively channel children's development through the creation of sets of experiences and opportunities. Socialisation can occur either directly or indirectly... They will also learn the basic uses of literacy through watching their family, for example, they will see their mother making a shopping list, writing a message or a phone number, consulting books to find something out. By the time these children go to school, even though they may not be able to read and write, they understand how books work and the role that literacy will play in their lives... (Machet, 2001:3)

\section{Home literacy practices: TV and radio programmes in urban homes}

Television (TV) and radio could distract children from their academic work, but it can also be useful tool in introducing children to different discourse practices related to literacy practices critical to educational discourses. It was clear that urban parents visited in this study create opportunities for their children to be exposed to educational programmes on TV and radio. We observed that these events gave the children pleasure and at the same time fostered literacy development. Through access to radios and TVs in their homes, they have access to a variety of speakers and many of whom present good models from which the children can learn pronunciation, sentence structures, reasoning, analogies and gain information (see Cope and Kalantzis, 2000). In many cases the information presented on the programmes is related or is part of the syllabus content these children are learning at school. In such cases the children get an opportunity to engage with the information twice but through different modes. This enhances internalisation and it should be easier for them to remember the facts they have heard over and over again when they are required to write them in exams than for those who do not get such opportunities to get the facts outside the classroom (cf. Cope and Kalantzis, 2000 for similar arguments). 
Besides, watching TV and listening to the radios with their parents and then discussing those programmes together enhances the meaning-making process and gives them the kind of confidence they need to be able to interact with their teachers at school. This makes them active participants in the learning process. This is clear in the following extracts from field notes from urban homes:

- Revising notes

- Do their school homework and that organised by the parents.

- Discuss class work with friends, neighbours, siblings, visitors, parents and other adults they stay with.

- Reading story books, plays, poems, textbooks, newspapers, magazines, notices, notes, charts, cards, adverts on TVs and brochures, labels on food packages, medicine and insecticide cans, messages left for them by parents and sometimes their parents' books. The $P 3$ added that they also read to/and with their parents.

- Talking about what they read.

- Writing letters to friends, siblings and relatives, messages for their parent, siblings.

- Fill in crossword puzzles and make, cost and use shopping lists.

- Watch religious, academic, political discussions, news telecasts, sports and films programmes on TV and sometimes make notes from TV and radio programmes.

- Listen to varieties of programmes on radio.

- Discuss the programmes they see and listen to with friends, neighbours, siblings, visitors, parents and other adults they stay with.

- Also watch their parents work with their own books.

- Play games such as scrabble, chess etc.

Not only that, it is also clear that urban parents take advantage of their surroundings and anything at their disposal for the benefit of their child's education. They set aside some time to 'read with their children'. One parent explained that:

...this starts with just seeing and talking about the pictures with the children, any pictures, whether those in the newspapers or in those little books we buy for them. Gradually you move from one level to another.

It was also evident that the urban parents take advantage of the children's 'curiosity' and deliberately prime it towards the kind of critical thinking required at school. Consider the following comment from a parent:

...you know these young children are curious and they want to learn, they have that urge to know. They are curious. That is why they ask so many questions. Answering those questions is important because as you give them the answers you stimulate their brains to think a lot more...this is good for their mental development.

\section{Home literacy practices: $T V$ and radio programmes in rural homes}

Most of the rural areas in the Iganga district do not have electricity since it is available only to those who live along the main roads. But even then most of the homes along these roads cannot afford having it in their homes because installing it and paying for the consumption are well above their means. Consequently all the rural homes did not have TVs. All the 
homes had radios but in one home we learnt that it is only switched on when it is time for news and some discussion programmes of the fathers' interest.

The radio in one of the rural home played only music for most of the time the researcher was in this home. The children seemed to be interested in music only. The researcher asked the mother whether they sometimes listened to news and other programmes and she confessed that she had no time for that. She said that the children hardly got a chance to listen to the radio when their father was away. When he was home, however, her husband listened to news and other discussion programmes and:

...when there is anything interesting he tells us and he sometimes discusses some of those things with the bigger children. But occasionally if the children get a chance to use the radio when the father is away they only listen to music. That is very rare because he says they waste the expensive batteries.

Similarly, in another rural home, although there was a radio, nobody showed any interest in it except the little children who enjoyed dancing whenever there was music playing on it. When asked whether they ever listened to any other programmes, two of the mothers confessed they sometimes did but it was not a habit they were keen on. The father brought out the radio but he left it playing music (possibly because of the 'visitor' [that is, the researcher]). One of the older children told the researcher that 'in most cases the radio is controlled by the father and since he is hardly at home, nobody really takes a lot of interest in it'.

The rural children in the study, therefore, had none of the benefits, such as exposure to knowledge, information and models and literacy practices which give pleasure and aided self expression that the urban children in the study enjoyed.

\section{Home literacy practices: Scaffolding as literacy mediation in urban homes}

Another interesting aspect identified as part of the acculturation process that was saliently different in the two settings was the quality of the interaction between the parents and their children. It was observed and also reported by the respondents that the urban parents freely interact with their children about their academic work, the programmes they watch on TV and those they listen to on radio as well as matters of interest in their day to day lives. The parents really seemed to place a high value on education. Below are examples of parent-child interaction observed in urban and rural areas. It is important to note that all the interaction between parents and children in urban homes were in English, while those in rural homes were in Lusoga.

In one urban home, the following conversation was observed.

Parent: Peter what did you learn in English today at school?

Peter : We did comprehension. We read the passage about the mad man and the slave.

Parent: That sounds interesting tell me about it.

[Peter then narrated the story and the two discussed it at length.]

Another interaction heard during this study in one of the urban homes was:

Parent: Hey where are you going? 
Child: Mom, I am going to see a movie. Silent Witness is about to begin.

Parent: Have you finished doing your homework?

Child: Yes Mom, all the exercises, even those numbers you told me to rewrite.

Parent: Let me see your homework and class work books first.

The child ran off to get the books so the parents could monitor the homework.

Contrast the observation above with two examples of common interaction literacy practices in the rural homes in the study:

Mother: Tom, run to the house and bring the plates and wash them.

Tom: Okay, Mother.

Mother: Where is Sarah?

Tom: $\quad$ Playing outside.

Mother: Tell her to get me some water [from a well 2 kilometres away].

Another example of common interaction heard during this study in the rural homes was:

Parent: When you get back from school today you go to Njayo's (relative) home and ask him to come over and see me tomorrow.

Child: Yes, Papa, I will go.

Parent: Make sure you come early. You know Njayo's home is very far and I want you to be back before dusk.

Basically, most of the parent-child interactions observed in rural homes relate to parents sending the children on errands. Thus, for the rural homes observed, 'literacy' practices relate to chores in the homestead and community, but unlike urban homes, the practices do not seem to directly link with the school.

From the examples of the kind of interaction between the urban parents and their children we could tell that the parents were very concerned about the children's education, they were ready to scaffold it and thus facilitate the process of acculturation. That is not the case in the rural homes. The interaction between the rural parents and their children is far from being school-oriented. This suggests differences between the urban and the rural parents' attitudes to their children's education and the value they place on it. It could also be argued that in the urban homes visited, parents helped their children to make connections between their various interactions, such as with TV, and the school.

Scholars have underscored the importance of the role of home literacies and parental and/or caregivers in the development of the children's schooled literacy. For instance, joint book reading, the number of books in the home, access to literacy artefacts (e.g., crayons, pencil and paper), and literacy interactions (e.g., visits to the library and the child and adult making shopping lists) are important for learning about the purpose and value of print and ultimately for learning to read (Payne, Whitehurst \& Angell, 1994; Purcell-Gates, 1996; Teale \& Sulzby, 1986).

The process in which urban children read, watch TV and listen to the radio with their parents and also discuss what they read, hear and see as well as many other academic and nonacademic topics advances language development. It increases the children's understanding of vocabulary and concepts, structure of story narratives, and decontexualised language as well 
as the conventions of print, letter-sound correspondences. The adults scaffold and support the children's interactions allowing them to acquire higher levels of skills. Certain styles of interactions such as describing, labelling, and focusing on meanings and inferences are also developed. All these particularly facilitate literacy skills (Roberts, Burchinal \& Durham 1999: 236).

On the other hand, there is very poor infrastructure and a lack of many of the basic social amenities such as public libraries in the rural areas. Most parents have not been to school and are too poor to afford basic amenities let alone books for home libraries. The children from the rural areas have very little, if any, access to printed material. If they chance to get a newspaper, it will be one brought home by a town dweller at the weekend or month end as s/he comes to visit the family. There are very few government dispensaries and even these lack drugs. Most of the rural population still depend on local herbs for treatment and when they buy medicine they do so from local private drug shops where a few tablets are wrapped in pieces of paper on which the dispenser writes just the dosage like ' $2 \mathrm{X} 3$ ' and gives oral instructions: 'Mira abiri emirundi esatu buli lunaku' that is, 'Take two tablets, three times a day'.

\section{THE CHANGES THAT ARE NEEDED}

\section{Skills development, media of instruction and language of examination}

Kyeyune (2004: 78) laments the unavailability of written policy guidelines in Uganda on the implementation of language in education, leading to a situation where 'schools continue to use English as a medium of instruction even in nursery school'.

The research reported in this study suggests that supportive interactions and meaningful scaffolding and the exposure to vast print materials, albeit it in English, help urban learners acquire and develop the skills that are important to academic success.

The skills developed by the rural children from practices such as listening to instruction and a few folk stories are also very useful (Gregory \& Williams, 2000: 53) but the difference that comes in to play here is the quality, frequency, scope and intensity of access. The urban learners in the study have quality and frequent exposure to a variety of types of listening. The rural learners in the study, on the other hand, have far less exposure and what they do have is narrower in scope and less frequent.

According to Francis (2000: 44), the narrative genre such as found in folktales enables children acquire textual competence a critical ingredient in the initial literacy development in comprehension skills. The problem here is that folktales do not seem to feature strongly in rural homes. Furthermore, whereas the narrative discourse pattern is mainly available in the L1 oral modality in rural areas, it is available in both the written and oral, as well as in both the L1 and the L2 in urban areas. In this regard, there would be need for training and workshops for rural teachers, in particular, on the use of narrative genres as transitional links on the two-way bridge of maintenance biliteracy and as a way to facilitate learners' access to the less transparent expository texts, and academic discourse in general (Francis 2000). Gough (2000) and Gough \& Bock (2001) illustrate how 'primary discourse' as found in activities such as oral folktales and praise singing among the Xhosas could be used as a 
stepping stone into 'secondary discourse' or opaque expository texts as found in academic discourse.

There is another factor in the development of literacy practices. The medium of instruction is not the same in the two settings. For the first four to five years or more of education, the rural schools use the mother tongue (Lusoga), and urban schools use English. This scenario results from two factors namely: as a directive of the language policy in education and as a choice, at least by the urban parents. Ironically, the children who have been taught in their mother tongue are disadvantaged. This is because at end of primary education, all the learners are expected to write the examination in English, thereby disadvantaging rural students as they have had very little exposure to English. A simple solution would be to change the policy to allow learners from rural areas write their examinations in the mother tongue. This is in the hope that such a solution did not lead into a situation like the one described by Krishnamurti (1990: 19), where the Indian Education Commission's (1954-1964) recommendation for use of the mother tongue and examination up to tertiary education, resulted in the creation of two streams of students: 'those with the English medium having a definite advantage over the regional language medium students, both in employment and postgraduate education' (Krishnamurti 1990:19). Citing Krishnamurti (1990), Khoo, Kreher \& Wong (1993) and Tickoo (1995), Banda (1996) argues that such a scenario in the long run worsened the position of the mother tongues as English became more sought after than before. The situation is similar to the enforcement of Bantu Education in South Africa, whose failure served to give mother tongue education a bad name among African language speakers. The result is that some L1 African language speaking learners and parents demand English language instruction (Banda 2003, 2004).

However, we want to point out that the issue here is not just about length of instruction in a particular language. The quality of education on offer and other socio-economic factors in the environment favour the urban learner. The situation in South Africa is similar. Citing 2001 and 2002 senior secondary school leaving (Matric) results (Ministry of Education SA, 2003), Banda (2004) concludes that learners from rural areas of South Africa are less likely to get entry into tertiary education than their urban counterparts, and similarly L1 speakers of African languages who go to former 'white' Model C schools and through ESL tend to do better academically than their counterparts in the former 'black' DEC schools, whatever the language(s) of instruction.

Similarly, citing Nsibambi (2000), Pattanayak (1986), Schmied (1991) and Stroud (2001), Kyeyune (2004: 83) takes the view that in Uganda 'the argument cannot be easily concluded in favour of mother tongue or English'. Moreover, she argues that a change in medium of instruction to the mother tongue will not guarantee academic competence among African learners. The problem, as this study has also shown, is that 'it is not certain that teachers would do much better if mother tongue was the medium of instruction, for their failure is not simply in the use of English' (Kyeyune 2004: 83).

This puts into perspective research which shows that exposure to supportive literacy practices and the language used in academic discourse gives learners the language proficiency which tends to have a strong effect on their academic success (Barton, 1999:151; Machet, 2001; National Centre for Curriculum Research and Development [NCCRD], 2000; Wasik, Dobbins and Herrmann, 2001: 444-451). McGroarty (1996:19) asserts that the amount of exposure to the language of study affects learners' comprehension of that language. We want 
to argue that the urban children are helped by the school and the home communities to develop their linguistic skills in the language of education/examinations by virtue of the quality of exposure resulting from superior resources, infrastructure, teaching material and well trained teachers, as well as other socio-economic factors discussed above. On the other hand, learning through the mother tongue, though desirable, is not enough to help, rural children acquire the kinds of discursive and literacy practices required for academic success.

At the same time, a situation where the education system of a country favours only 12 percent of its mainly urban citizens cannot go unchallenged. As Answorth (1985 cited in Kyeyune 2004: 83) argues, language in education fails when the language needs of some individuals are addressed while those of others are not. Clearly, then the government needs to be made aware of this failure in its language education policy. There is also need to provide rural schools with resources such teaching material in both English and the mother tongue, infrastructure such as (mobile) libraries, as well as training for teachers and school managers in modern classroom practice and school management. It is clear that the problem of the initial literacy development in rural areas is more than just a matter of choice between English and the Ugandan mother tongues.

Considering the argument for an inclusive citizenship, it might also be useful to explore bilingual education combining English and Ugandan mother tongues. However, Kyeyune (2004) cautions about the bilingual options because of the multilingual nature of Ugandan classrooms. Mother tongue pre-school literacy enrichment programmes such as have been proposed for South Africa (cf. Menkveld and Pepler 2004) cannot necessarily be applied to the Ugandan classroom where learners come from diverse ethnic and language backgrounds. Similarly, Banda (1996: 115) cites UNESCO (1964), which at the eve of Zambia's independence in 1964, uncharacteristically recommended that English be declared as medium of instruction from primary education, because in its judgement the multilingual situation inside and outside the classroom made it impossible to implement mother tongue education for all:

A child, therefore, may have begun in his mother tongue; changed to the main official vernacular, if that is not his mother tongue, after two years; changed to English as a medium of instruction two years later .... We recommend that a policy decision be made to introduce English as the universal medium of instruction from the beginning of schooling. (UNESCO (1964: 24)

The Ugandan sociolinguistic situation is not so much different from Zambia's. However, the bilingual option that might be useful in Uganda is one based on the systematic mix of several African tongues with English in the classroom. The idea here is to use the 'language of play'based multilingual programme (see Banda 2005), in which the different languages children come to school with are used in the classroom. The idea is to develop initial academic literacy by making use of whatever concepts a child already knows in whatever language. In primary 1, for example, teachers could be trained to use the several tongues found in their area for initial literacy development. The learners can subsequently be eased into English medium of instruction after grade 4 or later, but still retain an African language as a subject; alternatively, teachers could adopt one of the African languages as the language of learning after grade 4, while retaining English as a subject. But this is clearly a subject for another paper. 


\section{Narrowing the gap between home and school-based literacies}

We have already discussed the importance of parents' mediation on the development of their children's supportive literacy skills. Barton argues that:

From their experience in the home children know about the particular language and literacy practices of their community. They have emergent theories about what language is, about what literacy is, and about how to learn. It is important to see how this knowledge is taken up by schools (Barton, 1999: 183).

While Street puts it this way:

Good educational practice today requires facilitators to build on what the learners bring to the class... (Street, 2001: 14).

What these scholars are articulating is that it is difficult to draw a line demarcating home literacies from the schooled literacies for the children like those in the urban learners in this study. Barton ascertains that:

...it is true that home literacy does not cease when children enter school, literacy does not shift from home to school. The home environment continues, with its own practices around reading and writing... what is of interest to school should be what children know... (Barton, 1999: 185).

The significance of this to this study is that the development of schooled literacies has part of its roots in the home literacies. It is true that even those children without high quality exposure to supportive home literacies can, and sometimes do well in schooled literacies but it is also apparently true, at least in this study, that supportive home literacies go a long way in enhancing the development of schooled literacies. If this study is anything to go by literacy practices in urban homes are closer to schooled literacies, than are literacy practices in rural homes, thus putting urban children at an advantage in terms of access to educational discourse.

Regarding the issue of parents' ideologies, values, and attitudes towards their children's education, what becomes clear is that how the parents feel towards education dictates their level and quality of mediation. This is determined by the parents' own level of education for three basic reasons. Firstly, if the parents are formally educated (as is the case with the urban parents in this study) then they are likely to have high value and positive attitudes and ideologies towards education, particularly, the kinds of literacies required at school. This also drives them into putting supportive artefacts, favourable environment and scaffolding systems in place for their children. Secondly, they are likely to engage a lot more in academic-related literacy practices in the presence of their children so that from an early age such children will have emergent theories about what literacy and/or education that will help them develop positive attitudes and high value for education which will end up acting as strong impetus in the acquisition of schooled practices. Thirdly, as in the case of the urban parents in this study such parents are more likely to have sources of income that will enable them to provide the necessary requirements for the development of the schooled literacies. 


\section{CONCLUSION}

In conclusion then, this study posits that home literacies impact on the schooled literacies. An exploration of the two aspects - the acculturation process and literacy practices of the learners - suggests the existence of a divide between the rural and urban learners in the Iganga district.

Based on the findings of this study the problem of the rural learners is basically lack of a variety of supportive literacy practices. There is need for the rural children to be more exposed to literacy practices that prepare them for schooled literacies.

The acculturation process is a major area of concern. This study ascertained that the acculturation process the rural learners undergo is wanting in many areas. The support the rural learners get from their parents does not lay the foundation for the rigorous school process. They hardly have any exposure to the written language before going to school and for many years of primary education they have very limited exposure to the language of the textbooks and examination. The cultural question also needs attention. Parents in the rural areas need to be sensitised so that they can learn to discuss various issues with their children as this will enable the children to overcome any inhibitions and participate fully in class. Ways should be found of forming partnerships between parents and teachers so that parents can play a role in initiating and scaffolding their children's formal education.

The contrasting fortunes between urban and rural learners are vividly captured in the diary entries illustrated in this study by 'Urban Home 1 and Rural Home 5' in the appendix. Ultimately, literacy as socio-cultural practice is linked not only to how people use 'speaking' and 'reading', but also it is related to issues surrounding the quality of people's way of living generally. Metaphorically, speaking then, urban dwellers in this study appear to speak, read and live texts that prepare their children for the kinds of texts they are likely to encounter at school. It also seems their whole of way of life is geared towards facilitating academic achievement for their children. For instances, texts such as posters, pictures, images on TV, diagrams, maps, etc., which have become part of the urban landscape and culture and are thus taken for granted, mean urban learners develop visual literacies (cf. Kress \& van Leeuwen, 1996). Urban children's exposure to different kinds of 'voices' on radio and TV urban children and their experience of engaging in broader literacy practices (for instance, urban children often are allowed to, or simply get away with 'arguing' with parents or older members of society etc.) are among the factors that give them a critical edge in gaining the ability to engage in educational discourse practices.

In short, urban dwellers engage in the kinds of discourse practices that give their children a head start in educational (schooled) literacy practices. Though the discourses that families of rural children engage are valuable, they generally do not include the literacy practices required at school. Chief among the barriers to learning in rural homes are cultural-related practices, such as parents or person in authority doing all the critical thinking and talking, while the younger members follow the instructions with little or no critical input. However, the biggest problem for rural areas is economic poverty. The deprived socio-economic condition under which rural families find themselves lends itself to impoverished literacy practices. Without written material and quality oral texts (there is not much quality oral tradition any more in rural areas and TV and radio are too expensive to maintain), there is little for rural communities in terms scaffolded literacies that would help with educational 
discourses. Therefore, addressing the growing divide in academic achievement between rural and urban homes, and addressing literacy problems in the rural areas should be done as part of a wider critical cultural awareness and poverty alleviation plan and programme.

\section{REFERENCES}

ANDERSON, A, W TEALE \& E ESTRADA. 1980. Low-income children's preschool literacy experiences: Some naturalistic observations. $Q$ Newsletter of the Laboratory of Comparative Human Cognition, 2: 59-65.

ANSWORTH, M. 1985. Beyond methodology: Second language teaching and the community. Cambridge. Cambridge University Press.

BANDA, F. 1996. In search of the lost tongue: Prospects for mother tongue education in Zambia. Language, Culture and Curriculum, 9(2): 109-119.

BANDA, F. 2003. I can't really think in English: Translation as literacy mediation in multilingual/multicultural learning contexts. Per Linguam, $19(1 \& 2)$ : 66-89.

BANDA, F. 2004. A survey of literacy practices in black and coloured communities in South Africa. In Muthwii, MJ \& AN Kioko (eds), New language bearings in Africa. Clevedon: Multilingual Matters, 10-33.

BANDA, F. 2005. Language regulations in Zambia and South Africa. Unpublished manuscript. Linguistics Department, University of the Western Cape.

BARTON, D. 1991. The social nature of writing. In Barton D\& R Ivanic (eds), Writing in the community. London: Sage, 1-13.

BARTON, D. 1999. Literacy: An introduction to the ecology of written language. Oxford: Blackwell Publishers Ltd.

BARTON, D \& R IVANIC (EDS). 1991. Writing in the community. London: Sage Publications.

BAYNHAM, M. 2001. Reading the weather; ruling passions, numeracy and reading. Practices on an Australian farm. Paper presented at the language in action seminar series, Linguistics Department, University of the Western Cape, 10 July 2001.

BAYNHAM, M. 2000. Narrative as evidence in literacy research. Linguistics and Education. 11(2): 99-117.

COLLINS, J. 1995. Literacy and literacies. Annual Review of Anthropology, 24: 75-93.

COPE, B \& M KALANTZIS (EDS). 2000. Multiliteracies: Literacy learning and the design of social futures. London: Routledge. 
FINNEGAN, R. 1973. Literacy versus non-literacy: The great divide. In Horton, R \& R Finnegan (eds), Modes of thought. London: Faber, 112-144.

FINNEGAN, R. 1988. Literacy and orality. Oxford: Blackwell.

FRANCIS, N. 2000. Riconces de lectura comes tosan Isidro: New contexts for biliteracy and language mantainance. Language, Culture and Curriculum, 13(1): 31-50.

GEE, JP. 1990. Social linguistics and literacies: Ideology in discourse. London: Falmer Press.

GEE, JP. 2000. New people in new worlds: networks, the new capitalism and schools In Cope \& M Kalantzis (eds), Multiliteracies. London: Routledge, 43-68.

GEE, JP. 2001. A sociocultural perspective on early literacy development. In Neuman, S \& D Dickinson (eds), Handbook of early literacy research. New York: Guilford Press.

GOUGH, DH. 2000. Discourse and students' experiences of higher education. In Leibowitz, B and Y Mohamed (eds), Routes to writing in South Africa. Cape Town: HSRC Publications, 43-58.

GOUGH DH \& BOCK, Z. 2001. Alternative perspectives on orality, literacy and education: A view from South Africa. Journal of Multilingual and Multicultural Development, 22(2): 95-111.

GREGORY, E \& A WILLIAMS. 2000. Work or play?' Unofficial' literacies in the lives of two East London communities. In Martin-Jones, M \& K Jones (eds) Multilingual literacies: Reading and writing different worlds. Amsterdam: John Benjamins Publishing Company, 37-54.

HALL, N. 1994. The emergence of literacy. In Stierer B \& J Maybin (eds), Literacy and learning in educational practice. Clevedon: Multilingual Matters, 188-194.

HEATH, B. 1982. Protean shapes in literacy events. In D Tannen (ed.), Spoken and written Language: Exploring orality and literacy. Norwood, NJ: Ablex, 91-117.

HEATH, B. 1983. Ways with Words: Language and Life in communities and Classrooms. Cambridge: Cambridge University Press.

HYMES, D. 1972. Towards ethnographies of communication: The analysis of communicative events. In Giglioli, $\mathrm{P}$ (ed.), Language and social context. Harmondsworth: Penguin Books, 21-33.

KHOO, R, KREHER, U \& R WONG (EDS). 1993. Towards global multilingualism: European models and Asian realities. Language, Culture and Curriculum 6(3): 197 317. 
KRISHNAMURTI, B. 1990. The regional vis-à-vis English as the medium of instruction in higher education: The Indian dilemma. In Pattanayak, P (ed.), Multilingualism in India. Clevedon: Multilingual Matters, 15-24.

KRESS G \& T VAN LEEUWEN. 1996. Reading images: The grammar of visual design. London: Routledge.

KYEYUNE, R. 2004. Challenges of using English as a medium of instruction in multilingual contexts: a view from Uganda. In Muthwii, MJ \& Kioko AN (eds), New language bearings in Africa. Clevedon: Multilingual Matters, 77-88.

MACHET, P. 2001. Addressing problems of literacy in disadvantaged communities. In Language Matters Studies in Southern Africa, 33: 1-24.

McGROARTY, M. 1996. Language attitudes, motivation and standards. In McKay, SL \& N Hornberger (eds), Sociolinguistics and language teaching. Cambridge: Cambridge University Press, 3-46.

MARTIN-JONES, M \& K JONES. 2000. Multilingual literacies. In Martin-Jones \& K Jones (eds), Multilingual literacies: Reading and writing different worlds. Amsterdam: John Benjamins, 1-16.

MINISTRY OF EDUCATION. 2002. Report on Primary Leaving Examination results. Ministry of Education: Kampala.

MINISTRY OF EDUCATION SA. 2003. Senior secondary school leaving results. Pretoria: Government Printers.

NATIONAL CENTRE FOR CURRICULUM RESEARCH DEVELOPMENT (NCCRD) 2000. Language in the classroom: Towards a framework for intervention. Pretoria: Department of Education.

NSIBAMBI, R. 2000. A language policy for national integration. Facilitators and inhibitors. In Parry, K (ed.), Language and Literacy in Uganda. Kampala: Fountain Publishers

PATTANAYAK, DP. 1986. Education use and the mother tongue. In B Spolsky (ed.), Language and education in multilingual settings. Clevedon: Multilingual Matters, 515.

PAYNE, A, G WHITEHURST \& A ANGELL. 1994. The role of literacy environment in the language development from children in low-income families. Early Childhood Research Quarterly, 9: 427-440.

PRINSLOO, M \& M BREIER. 1996. The social uses of literacy theory and practice in contemporary South Africa. Amsterdam: John Benjamins.

PURCELL-GATES, V. 1996. Stories, coupons, and the TV guide: Relationships between home literacy experiences and emergent literacy knowledge. Reading Research Quarterly, 31(4): 406-428. 
ROBERTS, J, M BURCHINAL \& M DURHAM. 1999. Parents' report of vocabulary and grammatical development of African American preschoolers: Child and environmental associations. Child Development, 70 (1): 92-106.

SAXENA, M. 1994. Literacies among Panjabis in Southhall. In Hamilton, M, D Barton \& R Ivanic (eds), Worlds of literacy. Clevedon: Multilingual Matters, 195 - 214.

SCHMIED, J. 1991. English in Africa: An introduction. London: Longman.

STREET, B. 1993. (ED). Cross-cultural approaches to literacy. Cambridge: Cambridge University Press.

STREET, B. 1984. Literacy in theory and practice. Cambridge: Cambridge University Press.

STREET, B. 1995. Social literacies: Critical approaches to literacy development, ethnography and education. London: Longman.

STREET, B. 2000. Literacy events and literacy practices: theory and practice in the New Literacy Studies. In Martin-Jones, M \& K Jones (eds), Multilingual literacies: Reading and writing different worlds. Amsterdam: John Benjamins Publishing Company, 17-29.

STREET, B (ED.). 2001. Literacy and Development: Ethnographic perspectives. London. Routledge.

STROUD, C. 2001. African mother tongue programmes and the politics of language: linguistic citizenship versus linguistic human rights. Journal of Multilingual and Multicultural Development, 22 (4): 339-355.

TEALE, W \& E SULZBY. 1986. Emergent literacy: Writing and reading. Norwood, NJ: Ablex.

TICKOO, ML. 1995. English in Asian bilingual education: From hatred to harmony. Paper presented at the conference on bilingualism through the classroom. Universiti Brunei, Darussalam, 5-9 June 1995.

UGANDA BUREAU OF STATISTICS, 2002 www.ubos.org/provresreport.pdf Accessed on 22 September 2004.

UNESCO. 1964. Education in Northern Rhodesia: A report and recommendations prepared by UNESCO planning mission 1963. Lusaka: Government Printer.

WASIK, B, D DOBBINS \& S HERRMANN. 2001. Intergenerational family literacy: Concepts, research, and practice. In Neuman, S \& D Dickinson (eds), Handbook of early literacy research. New York: The Guilford Press, 444-451. 
Biographic

Note

Felix Banda is head of the Department of Linguistics at the University of the Western Cape (email:fbanda@uwc.ac.za). His research interests are multilingualism, literacy and text/discourse analysis. Rebecca Kurundu is at present doing doctoral research on academic literacy development in Uganda at the University of the Western Cape (email: rfkirunda@yahoo.com) 


\section{APPENDIX}

Diary entries for Urban Home 1 and Rural Home 5

\section{Urban Home 1}

This home is situated in the main town in Iganga district. Both parents have good jobs. They have three children aged 12, 9 and 6 who are in P6, P3 and P1 respectively. These children go to 'good' schools in the sense that a majority of pupils from these school often qualify for university entrance. The father was also in the parents' focus group and he volunteered to be visited. I arrived at this home at 8.30 am and left at $7.20 \mathrm{pm}$.

Home 1 had a rich variety of literacy practice artefacts. There were calendars in the sitting and dining rooms and in the kitchen. There were charts for nursery school and P1 in the sitting room. One had numbers 1-100, one had the plain alphabet, one had the alphabet but with sets of words accompanying each letter and one had pictures of some of the household items with their names. I later learnt that these were for the P1 girl. There were also photographs with captions in the sitting room.

There was big book shelf with a wide range of books. Many of them were children books. These included many of the text books used from P1 to P6. The P6 boy told me that all the books he used in each class were bought by the parents and kept when he went to the next class. All these books were in English except two Bibles and two Hymn books. These were in Luganda. There were stacks of English newspapers and Time magazines on top of the book shelf.

In the boys' bedroom there was a table and two chairs. These, I was told, are used by the boys when they are studying. I saw several story books, a variety of charts for both SST and Science, copies of Young Talk, Straight Talk and the Children's Vision. The P3 boy told me a story he had read from one of the books and he read for me a part from the English Bible. He was fluent in English. I saw the boys' exercise books which they used at school. All of them were neat and orderly with very good work.

In the girl's room there were picture she had drawn pasted on the wall. There were also some simple story books from the 'Lady Bird' series. Later on the girl read for me one of these books and she seemed to know the story very well.

There was a TV and a radio in the sitting room. I was told that the children are free to watch and to listen to any program when the parents are not using these gadgets.

It is a decent home and the environment is good. It is a permanent house with running water and electricity. There is sufficient comfortable furniture and it is conducive for home study. The children have all the amenities that make life comfortable. 


\section{Rural Home 5}

This was a rural home but approximately three kilometres from the school. Both parents were basically peasants. The mother was in the focus group and she volunteered to be visited. The mother studied up to P5 and her parents had no money to keep her in school any longer. "I had grown big, I was about 16 years old [and] they (the parents) wanted me to marry before I conceive and embarrass them," she explained.

The father in this home lost his father while in P7 and that marked the end of his education. They had six biological children aged 16, 13, 11 and 9 in school. Their classes were S1, P6, P5 and P3 respectively and the other two were aged 5 and 3 and had not started school. They had other children staying with them because the home was near the school. I was told that during school time this home caters for 9-12 children. I visited the home during holidays when the other children had gone back to their homes. I arrived at this home at 10. $10 \mathrm{am}$. and left after $6.00 \mathrm{pm}$.

Like other rural homes visited, there were hardly any literacy artefacts in this home. I saw tattered children's exercise books. Compared to what I had seen in the urban homes the work done at school as reflected in the exercise books was very little. When I asked about the difference I was told that the teachers don't give much work because "they have a lot of pupils in their classes and marking would be even more difficult than they find it now if they gave a lot of work to the learners." There were many unmarked exercises in the books I saw. Some exercises were marked by fellow learners. I was told that the learners are sometimes asked to exchange the books then the teacher reads out the correct answers as they mark each other's books.

The children in this home had four exercise books each. I asked the mother how she copes with looking after so many children. She said that she sells some items like sugar canes, ripe bananas, maize and groundnuts at the school during mid morning and lunch break. This gives her some money to cater for the domestic needs and provide the children with books and pens. "Their father is not so much bothered," she said. Later I asked the children whether they see any other written material at home. The older two told me that they sometimes borrow some text books from the teachers without the headmaster's knowledge. [The Headmaster forbids teachers to loan books out for fear of losing them].They also admitted that though sometimes they buy things wrapped in old newspapers but they had never bothered to read such pieces of paper. There was a radio but for most of the time I was in this home it played only music. The children seemed to be interested in music only. I asked the mother whether they listen to news and she confessed that she had no time for that. She said that her husband listens to news and other discussion programs and "when there is anything interesting he tells us and he sometimes discusses some of those things with the bigger children." In this home the house is made of mud and wattle. There is one table and a few chairs. Some of the children sleep on the floor. The children's clothes and beddings are not so clean and some are tattered. The water source is a well about two kilometres away and the water looks milky and there is no electricity. The lighting they use are small 'lamps' made from small tins. A hole is made through the cover and a wick is inserted through that hole down to the paraffin which is put in the tin. It is called "tadooba" in Lusoga. 